Orientações para uma psicanálise contemporânea André Green São Paulo: SBPSP; Rio de Janeiro: Imago, 2008. 376 p.

A tradução recente do livro de André Green Idées directrices pour une psychanalyse contemporaine: Méconnaissance et reconnaissance de l'inconscient (2002), realizada pela parceria do departamento de publicações da SBPSP e da Editora Imago, deve ser vista pela comunidade psicanalítica brasileira como um acontecimento. Cabe, portanto, agradecer ao organizador desta excelente tradução, o dr. Paulo César Sandler, por esta bem-vinda iniciativa.

André Green é sem dúvida um dos analistas vivos mais importantes da atualidade. Green faz parte de uma vertente psicanalítica francesa conhecida como "clássica". Esta vertente permanece muito ligada à obra de Freud, que continua sendo vista como um texto da mais extrema atualidade e com a qual sempre vale a pena dialogar. Nesta perspectiva, encontramos junto a A. Green analistas como J.-B. Pontalis, Piera Aulagnier, Conrad Stein, Jean Laplanche, Joyce McDougall e Claude Le Guen, para citar os mais famosos. Estes analistas passaram pelo furacão lacaniano e aceitaram a necessidade do retorno a Freud, porém recusaram a forma e o conteúdo que Lacan deu a este retorno. Consequentemente, surgiu a necessidade de reinterrogar a obra de Freud reconstruindo os parâmetros metapsicológicos básicos, selecionando e organizando o conjunto da obra freudiana de um modo particular, que fizesse sentido num contexto contemporâneo e impulsionasse a clínica. A obra de André Green, que até o dia de hoje conta com 22 livros pu- 
blicados em francês e traduzidos em diversas línguas (inglês e espanhol, entre outras), ocupa neste grupo um lugar que se destaca pelo seu engajamento na luta pela sobrevivência da psicanálise, tanto pelo amplo desenvolvimento realizado a partir da obra freudiana, como pelo importante movimento de diálogo que ele empreende dentro e fora do campo da psicanálise. A retomada teórico-clínica na qual André Green tem se empenhado visa resgatar as diretrizes suscetíveis de abrir uma renovação da teoria que se impõe para ele como uma questão ligada à própria sobrevivência da psicanálise, mergulhada hoje numa ampla crise de identidade ligada à dispersão de seu saber e de suas práticas. Esta retomada se torna, por outro lado, uma necessidade urgente para responder aos inúmeros desafios impostos pela clínica não neurótica.

No momento atual em que se encontra a psicanálise brasileira, particularmente a psicanálise institucionalizada, a tradução e o estudo deste livro deve se tornar de extrema utilidade prática, pois permitirá uma orientação na torre de Babel com a qual os analistas se defrontam quando desejam aprofundar-se no estudo teórico-clínico. Cabe dizer que, por psicanálise contemporânea, Green entende por um lado o campo da teoria psicanalítica, feito pela imensa diversidade teórica pós-freudiana, e por outro o campo da clínica, feito de pacientes e situações que se encontram no limite da possibilidade de análise (pacientes borderline, narcisistas, de estrutura psicótica ou perversa, psicossomáticos...). O livro Idées directrices... se propõe, segundo o autor, a ser uma atualização do "Esboço de Psicanálise" escrito por Freud em 1938. Para atingir este ambicioso objetivo, André Green revisita sistematicamente os diferentes temas e discussões que ele desenvolveu em suas pesquisas realizadas nos últimos cinquenta anos. Sabemos que, após a morte de Freud, o saber psicanalítico foi fragmentado e dispersado. Assim, neste novo esboço, Green retoma 65 anos depois os dados fundamentais da prática e da teoria psicanalítica, apresentando os principais conceitos que atravessam a sua obra e que foram forjados a partir de suas conversas com os seus mestres (Melanie Klein, W. Bion, D. W. Winnicott e Jacques Lacan, entre outros) e pares (J. L. Donnet, J.-B. Pontalis, Didier Anzieu, Jean Guillaumin, René Roussilon...). O objetivo deste livro é, portanto, o de reatualizar, neste começo de milênio, as aquisições da psicanálise, teóricas e práticas, a partir de um movimento de diálogo que reúne e integra num conjunto coerente a metapsicologia freudiana e pós-freudiana. Cabe ainda dizer que este projeto, que poderia pela sua ambição se tornar totalizante, respeita a irredutível complexidade do psiquismo pela qualidade evocativa da escrita do autor. Assim, o pensamento clínico do qual emergem as conceitualizações de Green permanece próximo do espírito da produção criativa da metapsicologia freudiana, no qual o conceito procura remeter ao mundo afetivo que o contato com a experiência geralmente obscura e angustiante da clínica desperta nos analistas. 
Para convidar o leitor a se debruçar sobre esta obra-prima, destacaremos três pontos que nos parecem realçar a originalidade e a importância deste trabalho.

Olhando para o conjunto da obra de André Green, percebe-se que ela foi sendo tecida a partir de dois campos de pesquisa, a história da psicanálise e a clínica psicanalítica. Em relação a sua aproximação à história da psicanálise, que é na atualidade uma das maiores fontes da dispersão e da babelização do saber e da prática psicanalítica, a aproximação greeniana deve ser vista como um afiado instrumento contra o dogmatismo vigente nas principais instituições que ensinam psicanálise, que decorre geralmente de poderosas lealdades transferenciais. Assim, o leitor encontrará, num incomum prolegômeno intitulado "Breve história subjetiva da psicanálise desde a Segunda Guerra Mundial", uma recapitulação dos mais importantes acontecimentos na psicanálise após a morte de Freud. A. Green, contudo, nos adverte: "não espere encontrar um capítulo de um historiador, e sim um simples recenseamento, um passeio pela história da psicanálise, que terá certamente as marcas de uma visão subjetiva". O importante na leitura greeniana é possibilitar a cada analista ordenar as ideias e se debruçar a partir de um olhar retrospectivo sobre as teorias que foram interiorizadas no seu percurso de formação. O objetivo dessa maneira de construir teoria consiste em, ao se apropriar subjetivamente do conhecimento, ultrapassar o dogmatismo e o reducionismo para o qual a psicanálise tende a deslizar. A leitura dos livros de Green nos apresenta assim um psicanalista que, no exercício efetivo da sua clínica, se debate com as obras de pares e mestres para que, num corpo a corpo afetivo e intelectual com seus pacientes, crie e recrie a psicanálise em sua singularidade.

Após ter percorrido rapidamente a história da psicanálise e mapeado as principais problemáticas presentes na clínica contemporânea, Green divide seus ensinamentos em duas partes: uma prática e outra teórica.

Na primeira parte do livro, os conceitos clínicos são redefinidos a partir de uma longa e ampla experiência com os pacientes-limite e não neuróticos, possibilitando apresentar critérios que permitem pensar nas indicações e contraindicações terapêuticas. A originalidade e a riqueza da visão greeniana vinculam a indicação terapêutica a uma avaliação hipotética preditiva, que considera a possibilidade da utilização criativa por parte do paciente dos diferentes elementos que constituem a prática psicanalítica clássica (a não visibilidade do objeto, a capacidade de suportar a atitude de retraimento e de espera do analista, a interpretação da resistência e da transferência, a duração limitada das sessões, a tolerância às separações). Para Green, não se trata de uma avaliação puramente empírica, mas de saber se o paciente possui "a capacidade de estar só na presença do analista" (Winnicott) e se, a partir desta solidão artificial, ele poderá colocar à disposição do trabalho analítico um funcionamento mental próximo daquele que se observa no sonho, possibilitando a associação livre. Sendo assim, na avaliação preditiva os critérios 
nosográficos contam menos do que estes que se correlacionam com o funcionamento mental do paciente (frequência da compulsão à repetição, tendência à atuação, carências elaborativas marcadas por frustrações excessivas, estrutura masoquista do ego, importância das posições destrutivas, tenacidade das fixações e regressões). Estes aspectos, que deverão ser avaliados ao longo das entrevistas iniciais, poderão determinar a indicação de análise ou de psicoterapia e o ritmo desejável e possível do trabalho, que dependerá também da estrutura do paciente, de sua resistência, de sua demanda e de sua transferência consciente ou inconsciente. A clareza dos critérios propostos por André Green nos leva a refletir sobre a necessidade de ensinar psicoterapia nas instituições psicanalíticas, possibilitando ao analista adequar os elementos constitutivos do enquadre à patologia do paciente de maneira a promover o desenvolvimento de um processo analítico.

A parte teórica do livro é uma síntese das pesquisas metapsicológicas greenianas. André Green reabilita o conjunto da obra freudiana, dando ênfase ao processo evolutivo do pensamento e aos fatores que impulsionaram o percurso realizado pelo Freud. Sua hipótese é a de que o percurso realizado por Freud constitui por si só uma síntese do percurso da psicanálise como um todo. Esta aproximação permite ver a lógica que rege o percurso freudiano, apontar para o que Green nomeia de cortes epistemológicos e identificar as carências na teoria freudiana, particularmente em relação à questão do objeto, cuja resposta à demanda do sujeito aparece como condição absolutamente necessária para a constituição do psiquismo.

Por outro lado, o leitor que deseja unicamente se familiarizar com os conceitos greenianos encontrará neste livro cheio de surpresas um glossário muito esclarecedor sobre os conceitos mais originais desse autor, tais como o trabalho do negativo, o narcisismo de morte, a alucinação negativa, a função objetalizante e o conceito de limite, entre outros.

\section{Talya Candi}

Doutora em Psicologia Clínica pela Pontifícia Universidade Católica de São Paulo - PUCSP (São Paulo, SP, Brasil); membro do Departamento de Psicanálise do Instituto Sedes Sapientae (São Paulo, SP, Brasil).

Rua Rio de Janeiro, 338

01240-010 São Paulo, SP, Brasil

Fone: (11) 3666-3087

e-mail: talyasc@uol.com.br 